EGU2020-13433

https://doi.org/10.5194/egusphere-egu2020-13433

EGU General Assembly 2020

(c) Author(s) 2021. This work is distributed under

the Creative Commons Attribution 4.0 License.

\title{
Insights into the magma plumbing system of La Fossa di Vulcano (Aeolian Islands, Italy) using oxygen isotopes and clinopyroxene crystal structure
}

\author{
Rebecca Wiltshire ${ }^{1}$, Ralf Gertisser ${ }^{1}$, Ralf Halama ${ }^{1}$, Adrian Boyce ${ }^{2}$, Chiara Petrone ${ }^{3}$, Sabrina \\ Nazzareni ${ }^{4}$, Federico Lucchi ${ }^{5}$, Claudio Tranne ${ }^{5}$, and Roberto Sulpizio ${ }^{6}$ \\ ${ }^{1}$ School of Geography, Geology and the Environment, Keele University, Keele, UK \\ ${ }^{2}$ Scottish Universities Environmental Research Centre, East Kilbride, UK \\ ${ }^{3}$ Natural History Museum, London, UK \\ ${ }^{4}$ Department of Physics and Geology, University of Perugia, Italy \\ ${ }^{5}$ Department of Biological, Geological and Environmental Sciences, University of Bologna, Italy \\ ${ }^{6}$ Department of Earth and Geo-environmental sciences, University of Bari Aldo Moro, Italy
}

The presently active La Fossa cone, Vulcano, widely considered the most hazardous volcano in the Aeolian Islands, is characterised by alternating periods of Vulcanian to subplinian explosive events and lava flow effusion. It has formed over $5.5 \mathrm{kyr}$, last erupting in 1888-90 [1], and presently behaves in a quiescent, fumarolic stage. The volcanic deposits from the cone comprise 7 major formations: Punte Nere, Grotta dei Palizzi 1, 2, and 3, Caruggi, Pietre Cotte and Gran Cratere. Many of these commence with dilute pyroclastic density current (PDC) deposits and tephra fallout capped by lava flows, with a compositional range from shoshonite to rhyolite (52-74 wt.\% $\left.\mathrm{SiO}_{2}\right)$ [1]. Crustal xenoliths in some of the lava flows and PDC deposits signify the importance of crustal contamination in the La Fossa magmatic system [1]. Here, we present new oxygen isotope data of mineral (clinopyroxene, plagioclase) and glass separates and combine these with petrological and textural analyses as well as clinopyroxene crystal chemistry and thermobarometry to constrain the extent of crustal contamination and to determine if and where crustal contamination took place in the magmatic system of La Fossa.

Oxygen isotope data are presented for pumice, scoriae, breadcrust bombs, lavas and mafic magmatic enclaves of all formations of La Fossa. $\delta^{18} \mathrm{O}$ values range from $+6.0 \%$ to $+6.7 \%$ (SMOW) for clinopyroxene $(n=19)$, from $+7.0 \%$ to $+8.1 \%$ for feldspar $(n=15)$ and from $+8.3 \%$ to $+8.7 \% 0$ for obsidian glass $(n=2)$. Estimated $\delta^{18} \mathrm{O}_{\text {melt }}$ values are higher than that of mantle-derived magmas, indicating that crustal contamination is ubiquitous in the La Fossa magma plumbing system. $\delta^{18} \mathrm{O}_{\mathrm{fsp}}$ increases with the degree of magmatic differentiation, indicating feldspar is more contaminated in the more evolved products of La Fossa. However, no systematic variation is observed between $\delta^{18} \mathrm{O}_{\mathrm{px}}$ and whole-rock $\mathrm{SiO}_{2}$, indicating disequilibrium between clinopyroxene and plagioclase. The disequilibrium observed at La Fossa suggests that clinopyroxene is mostly xenocrystic in the more evolved samples. This is supported by clinopyroxene equilibrium tests. Single-crystal X-ray diffraction to determine clinopyroxene crystal structures is presented to 
constrain crystallisation pressures. Crystallisation pressure of magmas feeding explosive eruptions to between approximately 2 and $6 \mathrm{kbar}$, while magmas feeding effusive eruptions appear to have crystallised at a narrower pressure range. Our results indicate that crustal contamination is an important process at La Fossa that accompanies fractional crystallisation and magma mixing/mingling processes throughout the entire (deep to shallow) crustal magma plumbing system.

\section{References:}

[1] De Astis et al. 2013. Geol. Soc. London Memoirs. 37. 281-349. 